\title{
Building A Citizens Education Learning Community Through Online Collaborative Learning
}

\author{
Listyaningsih Listyaningsih ${ }^{1, *}$, Maya Mustika Kartika Sari ${ }^{2}$, Nur Siami \\ Fitriawati $^{3}$, Dhinendra Choirum Min Alfi Syach ${ }^{4}$, Reri Febriana \\ Umbas $^{5}$
}

\author{
1,2,3,4,5 Universitas Negeri Surabaya, Surabaya, Indonesia \\ *Corresponding author. Email: listyaningsih@unesa.ac.id
}

\begin{abstract}
Advances in technology have changed the way learning has been done so far. In the midst of the covid-19 pandemic, forcing all parties to use the internet in various ways, including in the world of education. The learning process carried out so far with face-to-face has turned into online learning. Citizenship education is education that must be given to all citizens in order to become good citizens. Citizenship education is also intended to build the nation's character. In order to achieve this goal of civic education, it is necessary to build a civic education learning community. One of the efforts that can be done is through the implementation of collaborative online learning models. In online learning allows students to study alone, in groups, and collaborate with peers and create a community or study group that can be done anytime, anywhere and in any situation. An indicator of the success of collaborative online learning is the formation of a learning community. Discussion activities, mutual opinion, mutual respect, care and good cooperation are important things to be realized in this learning.
\end{abstract}

Keywords: Citizenship Education, Learning Community, Online Collaborative Learning.

\section{INTRODUCTION}

In the current era of globalization and modernization, people must be able to follow the development of information technology that is growing rapidly. Competence of human resources is an important thing that must be improved in the face of advances in information technology today. The competence of human resources in the 21 st century emphasizes communication and collaboration skills as well as mastery of digital technology, which is an implication of globalization and the development of science and technology. So that 21 st century learning is no longer seen as a process of knowledge transfer but a process of communication and social interaction between students in building knowledge .. [1] The development of information technology, which is marked by the existence of the internet, makes the world without boundaries. Communication can take place easily and quickly. Various information can also be obtained quickly from various parts of the world. Mastery of technology in the field of communication and information today absolutely must be owned by every individual in order to be able to meet the demands of the times.
The covid 19 pandemic, forcing all parties to use the internet in various ways, including in the world of education, the Covid 19 pandemic, has indirectly brought many changes in the learning process. Learning done in the classroom so far has experienced a shift, from face-to-face learning to online learning. The learning process in schools and universities is carried out online during the covid 19 pandemic. Learning takes place online by utilizing the internet with various media such as zoom, teems, googlemeet whatsapp and others. In this online learning, students tend to learn independently. More student activities are carried out individually than in groups.

Online learning has advantages and disadvantages. The advantage is that learning can be carried out anytime and anywhere. However, there are also weaknesses, such as the results of research conducted by Maia, Beria Rodrigues, Pauli Cesar (2020) regarding online learning during the covid-19 pandemic, which shows that students experience much higher levels of anxiety, depression, and stress and experience psychological effects. which is worse when compared to students in the pre-pandemic period. The causes of stress on students include the large number of teaching materials, the lack of lecturer 
feedback, the quality of the lecturers and the number of assignments. During the covid-19 pandemic, student pressure and burden increased due to changes in systems, methods and learning models from face-to-face to online. Online learning that is done for a long time causes boredom and boredom.[2]

In order to overcome boredom, anxiety, stress, depression and other psychological effects, the online collaborative learning model can be one of the choices of learning models that can be applied. Collaborative learning provides many benefits that can be obtained by students, critical thinking skills and social interaction can be done both face-to-face and online. Collaborative learning provides social benefits, namely a social support system in the form of a more caring, supportive, committed relationship, a positive atmosphere that will contribute to psychological health, social competence and can develop students' self-esteem in developing a learning community.[2]

Online collaborative learning as an alternative model that can be applied in learning. Learning Citizenship Education, Civic education as one of the subjects given in schools and universities has a very important goal in forming good citizens. According to the National Council for the Social Studies (NCSS), the objectives of civic education are formulated as follows: "...civic education today seeks to create citizens who are informed, analytic, committed to democratic values, and activity involved in society (Robinson, 1967) [3] Based on this goal, there are three targets of citizens who have personal qualities, namely (1) informed citizens; (2) being analytical and implementing democratic values and being active in people's lives.

An informed citizen has personality qualities, namely (a) has knowledge and ability to solve problems; (b) have an awareness of the role of contemporary science; (c) have readiness for the effectiveness of economic life. Citizens are analytical, have the ability in terms of: (a) the ability to make value decisions regarding world changes; (b) acceptance of new facts and new ways of life, new ideas and new ways of life. Citizens who are able to implement democratic values and are active in life in society are expected to have the ability (a) to participate in decision-making; (b) believe in the principles of equality and freedom; (c) foster national pride and international cooperation; (d) cultivate creative arts and humanistic feelings; (e) have feelings of humanity towards fellow citizens; (f) development and application of democratic principles. [3](in Hakim, et al, 2014:10)

In an effort to realize the goals of civic education, online collaborative learning can be an option to be applied in learning. Through online collaborative learning students can study in groups and collaborate with peers and create a community or study group that can be done anytime, anywhere and in any situation. Therefore, in this article, we will study about building a civics education learning community through online collaborative learning.

\section{LITERATURE REVIEW}

\subsection{Learning Community}

A learning community is a place where learning citizens and adults as active learners can meet certain needs/interests for them and where everyone can learn and develop their abilities (Roland Barth, 1990). Meyres and Simpson (1998) describe a learning community as a cultural setting where everyone can learn and become a good person. Collay and colleagues (Collay, Dunlap, Enloe, \& Gagnon, 1998) "noted that not only are individual and collective growth cherished in a learning community but also the processes for attaining that growth are valued". This is in line with the opinion of Speck (1999) that the learning community is one place to increase value in the learning that is carried out. [4]

According to Bruce Tuckman in Francesca, Marco, Angelo, and Giuseppina (2010) revealed that there are four phases that occur in the development of a learning community. The first phase is forming, the phase where the community starts based on enthusiasm and relationships. The second phase is storming, the phase to determine roles and responsibilities in the community. The third phase is norming, the stage to determine the rules in the community. The last phase is performing, which is a phase where members can interact to share knowledge and make decisions.

The characteristics of the learning community according to Kruse, Louis, and Bryk (1995) in Chris Kelly (2014) are: [4]

TABLE I. CHARACTERISTICS OF LEARNING COMMUNITY

\begin{tabular}{|l|l|}
\hline & \multicolumn{1}{c|}{ Dimension } \\
\hline characteristics & $\begin{array}{l}\text { Dialog; focus on student learning; practice skills; } \\
\text { cooperation; share values and norms }\end{array}$ \\
\hline condition & $\begin{array}{l}\text { There is a time to meet for discussion, closeness, } \\
\text { mutual learning from each other; empowerment }\end{array}$ \\
\hline $\begin{array}{l}\text { Human } \\
\text { Resources }\end{array}$ & $\begin{array}{l}\text { Open to improvement; mutual trust and respect; } \\
\text { supportive leadership; live in society; theory } \\
\text { skills }\end{array}$ \\
\hline \multicolumn{2}{|c|}{ Source:[4] }
\end{tabular}

Based on table 1 , in the learning community there will be dialogue activities, mutual cooperation, sharing and caring. So to be able to do this, there are meetings held between individuals both face to face and online. Individuals with other individuals can teach each other, trust each other and support each other. Students with other students will work together in completing the given task.

\subsection{Civic education}

Civic education is an education/learning program that programatically-procedurally seeks to humanizing, civilizing and empowering humans, in this case students (self and their lives) to become good citizens as the constitutional juridical demands of the nation/state concerned [5](. In addition, the National Council for Social Studies (NCSS) [6] defines Civic Education as follows: Civic education is a process that includes all positive influences aimed at shaping a citizen's perspective on his role in society. Our youth are helped to obtain an awareness of our national goals, the 
common good, and the process of self-government through Civic Education, which comes partly from official schooling and partly through family influence.

In this definition, the definition of civic education is further emphasized because the material includes the positive effects of education in schools and education outside the classroom/school. These elements must be considered in preparing civic education which is expected to help students understand and appreciate national ideals, make smart decisions, in various personal, community and state problems.

Citizenship education has the aim of developing the individual potential of Indonesian citizens, which is expected so that each individual has (a) basic beliefs, morals and character, insight and adequate intellectual and social skills as good and intelligent citizens; (b) the ability to take initiative and be creative for various dimensions of the life of the people of the nation and the State of Indonesia and mankind in the era of globalization. Citizenship Education in achieving these goals is very important at every level of education and is directed at the development of intellectual intelligence, emotional intelligence, spiritual intelligence, social intelligence as well as creative and innovative intelligence.[7]

Civic education as an educational program has a very important goal in shaping the character of citizens. Caring attitude, cooperation, honesty, responsibility, independence are the characters to be realized in addition to knowledge about citizenship.

\subsection{Online Collaborative Learning}

Collaborative learning that takes place online is known as online collaborative learning. Collaborative learning, according to Staples (2007) and Sato (2007), is a product of shared ideas, in which students present, listen to, and respond to each other's ideas, then work together to construct meaning or knowledge by joint efforts in diversity or difference.[1] Collaborative learning is a group learning strategy in which students in groups are encouraged to interact with one another and study together in order to better their understanding of one another.

Collaborative learning is a group learning model that emphasizes the process of sharing ideas through interaction between students with different views with the aim of increasing each student's understanding. [1] So, in collaborative learning, learning is carried out in groups consisting of two or more people, who work together and interact with each other to improve understanding of a material. In the implementation of collaborative learning, it can be face-to-face or online. Collaborative learning that utilizes the internet as a means of learning is referred to as online collaborative learning.

In the twenty-first century, online learning has become a need. Distance, place, and time are not barriers to learning. Learning can take place everywhere and at any time. Learning activities are no longer conducted face-to-face but rather via the internet; (b) the learning experience is dependent on who determines how knowledge is acquired; and (c) communication is a crucial factor in synchronizing the learning process.

There are three main principles in carrying out collaborative classes [8] (Barkley, 2007: 5):

1. Cooperative skills are taught. Practiced and feedback is given on how well the skills were used

2. The class is encouraged to be operated as a cohesive group

3. Individuals are given responsibility for their own learning and behavior.

For some scholars, it comprises more or less any collaborative action inside an educational topic, such as studying course material or exchanging course assignments, according to (Dillenbourg, 1999). The word 'collaborative learners' would be a better fit in this case. This means that collaborative learning does not have to be limited to two or more persons; sharing resources or tasks can also be considered collaborative learning.[1]

According to Arend (2020) collaborative teaching consists of 6 steps, namely:

1) Delivering goals and motivating learners

2) Presentation of information in the form of demonstrations or through reading materials

3) Organizing learners into study groups

4) Guiding group work and study

5) Evaluation of what has been learned so that each group presents their work

6) Give awards both as a group and individually [1]

According to Harasim (2012), Online Collaborative Learning is a learning approach in which students are encouraged and coached to collaborate in order to build knowledge in a creative and conceptual way. While online tutors play an important role not only as members of the community, but also as a link between the learning community and subject expertise, they must be active and engaged. [9]

Instructure have a very important role in facilitating discussion activities and helping to analyze or solve problems. Online collaborative learning emphasizes the teacher's role in facilitating and transferring knowledge. The interesting thing about collaborative learning is that students become actively involved in building their own knowledge through discovery, discussion and expert guidance. Several research reports show the advantages of collaborative learning, namely improving academic performance, developing soft skills [communication, collaboration, problem solving, and critical thinking skills, and increasing satisfaction in learning. [10]

\subsection{Building a Citizenship Education Learning Community through Online Collaborative Learning}

Over the years, online collaborative learning has proven to be beneficial due to its demonstrated adaptability on numerous levels, including pedagogical design, learning situations, learning content, and online tutoring. Learning communities and collaborative 
learning are two words that are often used interchangeably. Collaborative activities are an important aspect in the growth of learning communities. [11]

The findings of a study conducted by Syoytcheva (2018) on 25 students in the context of distance learning French language courses show that collaborative activities have several advantages, including (1) the ability to exchange and share ideas, opinions, and new ways of working $(32 \%)$; (2) they are more interesting and fun $(28 \%)$; (3) they produce a better end product $(12 \%) ;(4)$ they unite and form a sense of belonging to a group $(8 \%) ;(4)$ they create opportunities (8\%) (4 percent).[11]

In the 21 st century, there is a need for learning design models that lead to the development of skills needed for the digital era. [11]. According to Syoytcheva's 2017 research, all students regard collaborative work to be 96 percent fascinating and 92 percent useful. However, $52 \%$ said that collaborative work is more difficult and time-consuming than individual work, especially when done online. Despite the fact that students find collaborative work more difficult, the majority of students (84\%) recognize its advantages and benefits. For students, what's interesting is that they can exchange and share information, ideas, and experiences (100 percent), share and/or confront different points of view (76 percent), change their minds when listening to other people's opinions (92 percent), develop teamwork skills (84 percent), and learn to tolerate other people's opinions and argue them without causing conflict (72 percent).[12]. Online collaborative learning as an alternative learning model that can be applied to online learning. Online collaborative learning is a learning activity through collaboration between students, students learn from each other through peers and share knowledge which is carried out online.

Collaborative learning emphasizes cooperation between students in groups. In forming collaborative learning groups by considering differences in academic ability, gender and student characteristicsActively following the lecturer's explanation, doing assignments in groups, giving explanations to their group friends, encouraging their group friends to participate actively, and discussing are all examples of collaborative learning practices. In order for activities to run successfully, particular talents, known as collaboration skills, are required. Communication and task allocation among group members can help to improve collaborative skills. By using collaborative learning, a learning community will be formed inadvertently. In learning through online collaborative learning models will make students learn from each other. In learning there is a reciprocal relationship or a mutual teaching relationship. From here will emerge mutual respect, a spirit of cooperation and work together to solve common problems, establish communication and friendship, provide assistance/help to people in need.

Some of the attitudes that arise in the application of online collaborative learning are important to instill in students when the learning process is included in Civic
Education learning. Civic educationis education that leads to the formation of good and responsible citizens.

Citizenship Education is a very important education in an effort to form character. Advances in technology have changed the face-to-face learning process into online learning. Although learning is carried out online, the formation of attitudes in students needs to be done. Learning outcomes are not only cognitive, but affective and psychomotor aspects need to be considered. Therefore, a meaningful, value-based learning experience is important to grow in Civic Education learning.

\section{CONCLUSION}

Civic education is an education that is very important in shaping character. Therefore, this meaningful learning experience is very important in order to build students' knowledge, attitudes and skills. Online collaborative learning can be an alternative learning model that can be applied in schools and colleges during the covid 19 pandemic. Online collaborative learning, if applied, will build a learning community. This learning community is a place to develop the abilities possessed by students in solving problems related to civic education.

\section{REFERENCES}

[1] A. Hamidy and D. Purboningsih, "Pembelajaran Kolaboratif Berbasis Online dalam Perkuliahan Filsafat Pendidikan Matematika," pp. 138-144, 2015.

[2] C. A. Napitupulu, K. Ananda, R. Praticia, and V. W. Rahmadini, "Implemetasi Pembelajaran Kolaboratif Daring (Online Collaborative Learning) Dalam Rangka Pembentukan Dukungan Sosial Mahasiswa PG PAUD FKIP Universitas Palangka Raya," J. Pendidik. Dan Psikol. Pint. Harati, vol. 16, 2020.

[3] S. Al Hakim, Pendidikan Kewarganegaraan dalam Konteks Indonesia. Malang: Madani, 2014.

[4] R. F. Ramadani, Setiawati, and M. Nastsir, "Cerdas Dan Bijak Memanfaatkan Internet," Indones. J. Adult Community Educ., vol. 2, no. 1, pp. 50-64, 2020.

[5] A. K. Djahiri, Esensi Pendidikan Nilai-moral dan PKn di Era Globalisasi. Bandung: Laboratorium PKn FPIPS-UPI, 2006.

[6] N. Sumantri, Menggagas Pembaharuan Pendidikan IPS. Bandung: Rosda Karya, 2001.

[7] Ismaun, Pendidikan Nilai Moral dalam Dimensi Pendidikan Kewarganegaraan. "Penataan Pendikan Kewarganegaraan pada Perguruan Tinggi Menuju Masyarakat Madani." Bandung: Laboratorium Pendidikan Kewarganegaraan FPIPS-UPI, 2006.

[8] E. E. Barkley, K. P. Cross, and C. H. Major, Collaborative Learning Techniques. San Fransisco: Jossey-Bass, 2005. 
[9] Harasim and Linda, "Learning Theory and Online Technologies," New York, 2017.

[10] S. N. Razali, F. Shahbodin, H. Hussin, and N. Bakar, "Online collaborative learning elements to propose an online project based collaborative learning model," J. Teknol., vol. 77, no. 23, pp. 55-60, 2015, doi: 10.11113/jt.v77.6688.

[11] M. Stoytcheva, "Students' perceptions of online collaboration in a distance learning French language course," AIP Conf. Proc., vol. 2048, no. December, 2018, doi: 10.1063/1.5082048.

[12] M. Stoytcheva, "Collaborative distance learning: Developing an online learning community," AIP Conf. Proc., vol. 1910, no. December 2017, 2017, doi: 10.1063/1.5014003. 